\title{
Immobilization of $\mathrm{Cd}, \mathrm{Zn}$ and $\mathrm{Pb}$ in sewage sludge using red mud
}

\author{
Zhen Liang $\cdot$ Xianjia Peng $\cdot$ Zhaokun Luan
}

Received: 12 January 2011/Accepted: 30 August 2011/Published online: 17 September 2011

(C) Springer-Verlag 2011

\begin{abstract}
Sewage sludge is an inevitable end by-product of sewage treatment. Land application provides a costeffective alternative for sewage sludge disposal. However, sewage sludge contains heavy metals that may limit its application. In this work, red mud was employed for the immobilization of heavy metals in sewage sludge. The effect of red mud amendment on heavy metal immobilization was evaluated using Toxicity Characteristic Leaching Procedure (TCLP) method. The TCLP results showed that the immobilization efficiency of $\mathrm{Cd}, \mathrm{Zn}$ and $\mathrm{Pb}$ was 100,92 , and $82 \%$, respectively, when sewage sludge was mixed with $10 \%$ red mud. Tests carried out in leaching columns demonstrated that heavy metal concentrations in the leachate of $10 \%$ red mud amended sludge were lower than those of the unamended sludge. Moreover, red mud decreased plant available heavy metal $(\mathrm{Cd}, \mathrm{Zn}$ and $\mathrm{Pb})$ content from 18.1, 17.2 and $14.6 \%$ to $6.9,11.4$ and $7.6 \%$, respectively. Sequential chemical extraction experiments showed that after sludge was amended with $10 \%$ red mud, exchangeable fraction was reduced and iron and manganese oxides fraction was increased. Red mud amendment can effectively immobilize $\mathrm{Cd}, \mathrm{Zn}$ and $\mathrm{Pb}$ in sewage sludge before land application.
\end{abstract}

Keywords Heavy metals - Immobilization - Red mud . Sewage sludge

\footnotetext{
Z. Liang $\cdot$ X. Peng $(\bowtie) \cdot Z$. Luan

State Key Laboratory of Environmental Aquatic Chemistry, Research Center for Eco-Environmental Sciences,

Chinese Academy of Sciences, P.O. Box 2871,

Beijing 100085, People's Republic of China

e-mail: xjpeng@rcees.ac.cn

Z. Liang

e-mail: Liangzh2004@163.com
}

\section{Introduction}

Sewage sludge is an inevitable end by-product of sewage treatment. The accumulation of sewage sludge from sewage treatment plants is of increasing concern with the development of society and economy. At present, disposal methods for sewage sludge include landfill, incineration, dumping and land application. Compared to landfill, incineration and dumping, land application is a preferable and practical option for the disposal of sewage sludge in China. Land application represents the most cost-effective way for final disposal of sewage sludge as it combines the recycling of plant nutrients and sewage sludge disposal at the same time (Gu and Wong 2004; Wong et al. 2001). The high content of organic matter and substantial nitrogen and phosphorus concentrations in sewage sludge suggest its use as a fertilizer in agriculture. However, land application of sewage sludge presents a potential threat to the environment because of the content of heavy metals in sludge, which may be aggravated if the heavy metals are mobilized in the soil to be taken up by plants or transported in drainage water (Alvarez et al. 2002; Angelidis and Gibbs 1991; Mingot et al. 1995).

Chemical immobilization has been developed for reducing mobility and solubility of heavy metal contaminants. A large number of different amendments have been proposed and tested for immobilization of heavy metals in soils. Amendments investigated for immobilization of heavy metals in soils include limestone (Basta and McGowenb 2004), phosphate rock (Hettiarachchi et al. 2000; Chen et al. 2003; Cao et al. 2003; Basta and McGowenb 2004; Scheckel and Ryan 2004; Cao et al. 2009), sewage sludge (Basta et al. 2001), natural zeolites (Gadepalle et al. 2007), beringite (Lombi et al. 2003), steel shot (Muller and Pluquet 1998) and fly ashes (Dimitris 
and Meng 2003; Querol et al. 2006; Ciccu et al. 2003; Kumpiene et al. 2007). Chemical immobilization will provide an attractive technology if the amendment is cheap and ease of application.

One industry product that has been shown to have great potential to immobilize heavy metals and reduce availability is red mud. Red mud is the residue of aluminum industry. It is alkaline and composed primarily of iron and aluminum oxides. The alkali can immobilize heavy metals by precipitation and the iron and aluminum oxides can immobilize heavy metals by sorption. It seems interesting to employ red mud, which is the cost-effective industrial residue, as an agent to immobilize heavy metals in sewage sludge.

The immobilization of heavy metals using red mud amendment in soils has been successfully demonstrated in many studies (Gray et al. 2006; Bertocchi et al. 2006; Lombi et al. 2002a, b, 2003; Brown et al. 2005; Garau et al. 2007; Liang et al. 2010). However, there have been few reports on the investigation of red mud as an amendment for immobilization of heavy metals in sewage sludge, especially in the sludge of China. Therefore, the present study focused on heavy metals immobilization in sewage sludge by red mud amendment. The objectives of this study were to: (1) explore the potential of red mud to immobilize $\mathrm{Cd}, \mathrm{Zn}$ and $\mathrm{Pb}$ in sewage sludge; (2) investigate the DTPA extractable (plant available) heavy metals $(\mathrm{Cd}, \mathrm{Zn}$ and $\mathrm{Pb}$ ) in sewage sludge by red mud amendment; and (3) investigate the speciation of $\mathrm{Cd}, \mathrm{Zn}$ and $\mathrm{Pb}$ after red mud immobilization.

\section{Materials and methods}

Sewage sludge and red mud

Sewage sludge samples used in this study were obtained from Xiaohongmen Sewage Treatment Plant, located at Chaoyang District of Beijing. In this plant, sewage treatment uses the typical anaerobic-anoxic-aerobic $\left(\mathrm{A}^{2} / \mathrm{O}\right)$ process and the sewage sludge is mechanically dewatered by belt press filters. The dewatered sludge was collected and kept in a refrigerator at temperature of $4.0 \pm 0.5^{\circ} \mathrm{C}$. The sewage sludge $\mathrm{pH}$ value was $7.13 \pm 0.05$ (1:2.5 soil water suspension). The electric conductivity (EC) value was 1,042 \pm $68 \mu \mathrm{S} / \mathrm{cm}$ (1:2.5 soil water suspension). The moisture content reached up to $83.0 \pm 0.9 \%$. The total organic matter value was $497.0 \pm 0.4 \mathrm{mg} / \mathrm{g}$. The total phosphorus content in the sewage sludge was $15.0 \pm 0.2 \mathrm{mg} / \mathrm{g}$.

Red mud was obtained from China Aluminum Industry Shandong Branch Company, the composition and properties of which were listed in Table 1. Mineralogical constituents were determined using X-ray diffractometry
Table 1 Composition and properties of red mud

\begin{tabular}{ll}
\hline Composition & Content (w/w, \%) \\
\hline $\mathrm{SiO}_{2}$ & 12.45 \\
$\mathrm{Fe}_{2} \mathrm{O}_{3}$ & 25.68 \\
$\mathrm{Al}_{2} \mathrm{O}_{3}$ & 10.98 \\
$\mathrm{CaO}+\mathrm{MgO}$ & 13.88 \\
$\mathrm{Na}_{2} \mathrm{O}$ & 5.76 \\
$\mathrm{~K}_{2} \mathrm{O}$ & 0.33 \\
$\mathrm{TiO}_{2}$ & 12.94 \\
$\mathrm{Loss}$ on ignition & 15.41 \\
$\mathrm{pH}$ & 12.55 \\
$\mathrm{Specific}$ surface area $\left(\mathrm{m}^{2} / \mathrm{g}\right)$ & 16.48 \\
$\mathrm{Crystalline} \mathrm{phases}$ & Hematite, bayerite, calcite, \\
& cancrinite, goethite, \\
& rutile and quarz \\
\hline
\end{tabular}

(SmartLab, Japan). Loss of ignition was determined at $750^{\circ} \mathrm{C}$ in accordance with ASTM D5142-02a (Arthur 2004). The specific surface area was determined by using the $\mathrm{N}_{2}$ BET method (Micromeritics ASAP2000, USA).

Immobilization experiments

As for the immobilization experiments, $100 \mathrm{~g}$ sewage sludge was thoroughly mixed with red mud to immobilize heavy metals. The dosages of red mud amendment were applied to the sewage sludge samples at mass ratios of 5 , 10,15 and $30 \%(\mathrm{w} / \mathrm{w}, \mathrm{dw})$, respectively. The mixtures were incubated in the dark at $25^{\circ} \mathrm{C}$ for 3 days. The mixture $\mathrm{pH}$ was measured at the end of the incubation, according to the standard method of International Union of Soil Sciences for soil $\mathrm{pH}$ measurement and the $\mathrm{pH}$ of the mixture was measured in de-ionized water at mixture/water ratio of 1.0:2.5 and extraction time of $30 \mathrm{~min}$.

\section{Batch leaching experiment}

Batch leaching test using Toxicity Characteristic Leaching Procedure (TCLP) was carried out to investigate the efficiency of red mud to immobilize heavy metals. The TCLP extraction solution was prepared by mixing $5.7 \mathrm{ml}$ acetic acid to $1 \mathrm{~L}$ de-ionized water, adjusting the $\mathrm{pH}$ to $2.88 \pm$ $0.05 .1 \mathrm{~g}$ incubated mixture was placed in a $50 \mathrm{ml}$ centrifuge tube, and $20 \mathrm{ml}$ of the TCLP extracting solution was added. Each sample was equilibrated for $18 \mathrm{~h}$ on a shaker, centrifuged, filtered. The filtrate was collected and acidified to $\mathrm{pH}=2.0$ for heavy metal concentrations measurement. The heavy metal concentrations were measured using inductively coupled plasma mass spectrometry (ICP-MS, PerkinElmer) and the immobilization efficiency was calculated as follows: 
$\eta=\left(1-\frac{C_{\mathrm{e}}}{C_{0}}\right) \times 100 \%$

where $\eta$ immobilization efficiency, $C_{0}$ the leaching heavy metal concentration of sludge without red mud amendment, $C_{\mathrm{e}}$ the leaching heavy metal concentration of red mud amended sludge.

\section{Column experiments}

Based on the batch leaching experiment results, $10 \%$ red mud amended sludge was chosen for the next column experiments. Column experiments were conducted to evaluate the feasibility of the long term immobilization efficiency by red mud. Polyvinyl chloride (PVC) columns with inner diameter of $4.0 \mathrm{~cm}$ and length of $50.0 \mathrm{~cm}$ were used. $300 \mathrm{~g}$ unamended and amended sludge samples were placed in the columns and de-ionized water was supplied by a peristaltic pump from the top of the columns at a flow of $10 \mathrm{ml} / \mathrm{h}$. Leachates were collected every $24 \mathrm{~h}$ for the measurement of heavy metal concentrations and the leaching experiments lasted for 7 days. The leaching of heavy metals from the amended sludge was compared to that of the sludge sample without red mud amendment.

Measurement of plant available heavy metals

For the measurement of plant available heavy metals, the incubated sample was dried at $60^{\circ} \mathrm{C}$ and milled to pass a $0.4 \mathrm{~mm}$ sieve. It was recognized that diethylenetriaminepentaacetic acid (DTPA) extraction provides a chemical evaluation of the amount of heavy metals that are available for plant uptake (Reyhanitabar and Gilkes 2009; Fuentes et al. 2006). According to Lindsay and Norvell's method, the DTPA extractable heavy metals were determined to be the plant available heavy metals (Lindsay and Norvell 1978). The DTPA extractable fraction was obtained by mechanical shaking $10 \mathrm{~g}$ of mixtures for $2 \mathrm{~h}$ with $20 \mathrm{ml}$ of $0.05 \mathrm{M}$ DTPA-0.01 M Triethanolamine (TEA) solution buffered to $\mathrm{pH}$ value of 7.3 (Miles and Parker 1979). The suspension was filtered through Whatman No.42 filter and heavy metal concentrations were measured.

\section{Analysis of heavy metal speciation}

In order to analyze heavy metal speciation after red mud immobilization, the incubated sludge sample was also dried at $60^{\circ} \mathrm{C}$ and milled to pass a $0.4 \mathrm{~mm}$ sieve. The conventional sequential chemical extraction method by Tessier et al.(1979), which is widely used in the investigation of heavy metal speciation in sewage sludge (Liu et al. 2007; Cai et al. 2007), was employed for the analysis of heavy metal speciation and the extraction procedure was shown in Table 2. The extraction was carried out in $50 \mathrm{ml}$ polypropylene centrifuge tubes. To each tube, $1 \mathrm{~g}$ samples were added. After each extraction step, the tubes were centrifuged at 10,000 rpm for $10 \mathrm{~min}$. The supernatant was filtered through $0.45 \mu \mathrm{m}$ membrane filter and the heavy metal concentrations were analyzed.

\section{Results and discussion}

Heavy metal content and speciation in sewage sludge

Table 3 shows the selected heavy metal content and speciation in the investigated sewage sludge. It can be observed that the total concentrations of $\mathrm{Cd}, \mathrm{Zn}$ and $\mathrm{Pb}$ in the sewage sludge were much lower than the pollutant concentration limits for land application of sewage sludge recommended by the USEPA. $\mathrm{Zn}$ was the predominant heavy metal contaminant in the investigated sludge. Similar results have been reported by Chen et al. (2003) and Qiao et al. (2003) who reported that $\mathrm{Zn}$ was the predominant heavy metal in the sewage sludge. $\mathrm{Cd}$ and $\mathrm{Pb}$ are also of concern because of their potentially harmful effects on humans and animals. The solubility of heavy metals mainly depends on the heavy metal speciation in sewage sludge. Sequential chemical extraction experiments indicate that heavy metal speciation was different for $\mathrm{Cd}, \mathrm{Zn}$ and $\mathrm{Pb}$ in the investigated sewage sludge. $\mathrm{Zn}$ was observed mainly in the organic matter and residual fractions, while in contrast, $\mathrm{Cd}$ and $\mathrm{Pb}$ were observed mainly in the organic matter and carbonate fractions.

\section{Batch leaching experiment}

The aim of batch leaching experiment was to determine the efficiency of red mud to immobilize heavy metals and the required percentage of red mud to add to sewage sludge. From the TCLP leaching behavior, it is clearly shown that the amended sewage sludge samples showed significant reduction in $\mathrm{Cd}, \mathrm{Zn}$ and $\mathrm{Pb}$ leachability compared to unamended sewage sludge. $\mathrm{Cd}, \mathrm{Zn}$ and $\mathrm{Pb}$ leachability decreases as more red mud amendments were used (Table 4). The immobilization efficiency increases as more red mud amendments were used. Red mud amendment at $10 \%(\mathrm{w} / \mathrm{w}, \mathrm{dw})$ significantly reduces the TCLP extractable heavy metals, which is comparable with that at $15 \%(\mathrm{w} / \mathrm{w}$, $\mathrm{dw}$ ) of red mud amendment. As a compromise between the immobilization efficiency and amendment cost, $10 \%$ red mud amendment was chosen as the amendment ratio for the next experiments. When sewage sludge mixed with $10 \%$ red mud, the amount of leached $\mathrm{Cd}, \mathrm{Zn}$ and $\mathrm{Pb}$ was reduced from $0.07,65.82$, and $2.94 \mathrm{mg} / \mathrm{kg}$ to $0,4.99$, and 
Table 2 Sequential chemical extraction experiments for heavy metals

\begin{tabular}{llll}
\hline Step & Treatment & Extraction conditions & Fraction \\
\hline $\mathrm{S} 1$ & $1 \mathrm{M} \mathrm{MgCl}_{2} \mathrm{pH} 7.0$ & $1 \mathrm{~h}$ shaking & Exchangeable \\
$\mathrm{S} 2$ & $1 \mathrm{M} \mathrm{NaOAc} \mathrm{pH} 5.0$ & $5 \mathrm{~h}$ shaking & Bound to carbonates \\
$\mathrm{S} 3$ & $0.04 \mathrm{M} \mathrm{NH}{ }_{2} \mathrm{OH}-\mathrm{HCl}$ in $25 \%(\mathrm{v} / \mathrm{v})$ & $6 \mathrm{~h}$ shaking at $96^{\circ} \mathrm{C}$ & $\begin{array}{c}\text { Bound to iron and } \\
\text { manganese oxides }\end{array}$ \\
& $\mathrm{HOAc}$. & & Bound to organic matter \\
S4 & $\left(\mathrm{HNO}_{3} 0.02 \mathrm{M}+30 \% \mathrm{H}_{2} \mathrm{O}_{2}\right) \mathrm{pH} 5.0$ & $2 \mathrm{~h}$ shaking at $85^{\circ} \mathrm{C}$ & \\
& $30 \% \mathrm{H}_{2} \mathrm{O}_{2} \mathrm{pH} 2.0$ & $3 \mathrm{~h}$ shaking at $85^{\circ} \mathrm{C}$ & \\
& $3.2 \mathrm{M} \mathrm{NH}_{4} \mathrm{OAc}$ in $20 \%(\mathrm{v} / \mathrm{v}) \mathrm{HNO}_{3}$ & $0.5 \mathrm{~h}$ shaking at $85^{\circ} \mathrm{C}$ & \\
S5 & $\mathrm{HF}^{-\mathrm{HClO}_{4}}$ & 30 min shaking at $96^{\circ} \mathrm{C}$ & Residual \\
\hline
\end{tabular}

Table 3 Heavy metal content and speciation in sewage sludge $(\mathrm{mg} / \mathrm{kg})$

\begin{tabular}{|c|c|c|c|c|c|c|c|}
\hline \multirow[t]{2}{*}{ Metal } & \multirow[t]{2}{*}{ Total content } & \multicolumn{5}{|l|}{ Speciation $^{\mathrm{a}}$} & \multirow[t]{2}{*}{ Pollution concentration limits } \\
\hline & & $\mathrm{S} 1$ & $\mathrm{~S} 2$ & S3 & S4 & S5 & \\
\hline $\mathrm{Cd}$ & $7 \pm 1$ & $0.85 \pm 0.21$ & $0.96 \pm 0.12$ & $0.60 \pm 0.17$ & $4.18 \pm 1.04$ & $0.70 \pm 0.08$ & $<39$ \\
\hline $\mathrm{Zn}$ & $1,098 \pm 17$ & $105.60 \pm 0.43$ & $14.31 \pm 2.08$ & $38.05 \pm 4.29$ & $643.08 \pm 84.50$ & $244.42 \pm 1.64$ & $<2,800$ \\
\hline $\mathrm{Pb}$ & $123 \pm 7$ & $19.12 \pm 0.09$ & $28.22 \pm 2.38$ & $13.44 \pm 3.10$ & $43.79 \pm 1.92$ & $19.26 \pm 1.74$ & $<300$ \\
\hline
\end{tabular}

The results are expressed as mean \pm standard deviation. Mean for three replicates

a Speciation: $S 1$ exchangeable, $S 2$ bound to carbonates, $S 3$ bound to iron and manganese oxides, $S 4$ bound to organic matter, $S 5$ residual

b Pollution concentration limits (USEPA. 1995. A guide to the biosolids risk assessment for the EPA Part 503 rule. EPA 832-B-93-005)

Table 4 The leachable heavy metal content in unamended and amended sewage sludge $(\mathrm{mg} / \mathrm{kg})$

\begin{tabular}{llrl}
\hline $\begin{array}{l}\text { Mass ratio of red mud } \\
\text { to sludge }(\%)\end{array}$ & $\mathrm{Cd}$ & \multicolumn{1}{l}{$\mathrm{Zn}$} & \multicolumn{2}{l}{$\mathrm{Pb}$} \\
\hline 0 & $0.07 \pm 0.004$ & $65.82 \pm 1.78$ & $2.94 \pm 0.21$ \\
5 & $\mathrm{ND}$ & $9.40 \pm 0.64$ & $1.11 \pm 0.01$ \\
10 & $\mathrm{ND}$ & $4.99 \pm 0.12$ & $0.53 \pm 0.01$ \\
15 & $\mathrm{ND}$ & $3.37 \pm 0.08$ & $0.42 \pm 0.01$ \\
30 & $\mathrm{ND}$ & $2.06 \pm 0.15$ & $0.34 \pm 0.02$
\end{tabular}

$N D$ Not detected (detection limit: Cd, 0.003 ppm)

$0.53 \mathrm{mg} / \mathrm{kg}$, respectively. The immobilization efficiency of $\mathrm{Cd}, \mathrm{Zn}$ and $\mathrm{Pb}$ was 100,92 , and $82 \%$, respectively.

\section{Effect of amendment on $\mathrm{pH}$}

It can be seen from the above results that with the increase in red mud dosage, the immobilization efficiency increases. However, the increasing red mud dosage will induce an increase in the $\mathrm{pH}$ of the amended sludge due to the alkalinity of red mud. The $\mathrm{pH}$ of the amended sludge should be considered. The $\mathrm{pH}$ value of the mixture as determined by red mud dosage was shown in Fig. 1. It was found in Fig. 1 that, $\mathrm{pH}$ of the amended sludge reach 8.49 at red mud of $5 \%$ and 9.39 at red mud dosage of $10 \%$. When red mud dosage reaches $15 \%$, the $\mathrm{pH}$ was 10.97 , which was high for land application. So a red mud dosage of $10 \%$ was employed in the following investigation.
It was generally believed that the leachability and bioavailabity of heavy metals from sewage sludge is depended on $\mathrm{pH}$. The $\mathrm{pH}$ of the sewage sludge affected the solubility of the heavy metals. It has been concluded that the $\mathrm{pH}$ of the sewage sludge has a significant effect on the immobilization efficiency, which increases with increasing $\mathrm{pH}$ (Schnitzer and Skinner 1966). For the elements of concern in this study, $\mathrm{Cd}, \mathrm{Zn}$ and $\mathrm{Pb}$ leachability decreases as investigated sewage sludge $\mathrm{pH}$ increases.

\section{Column experiments}

A column leaching test was set up to evaluate the long term immobilization efficiency. The heavy metal concentrations in the leachate of unamended and amended sewage sludge are shown in Fig. 2. It can be seen from Fig. 2 that the concentrations of the selected heavy metals decreased over time as the more soluble forms of the heavy metals were flushed out of the columns. During the investigation period, heavy metal concentrations in the leachate of amended sludge were lower than those of the unamended sludge, which indicated that red mud amendment addition could effectively immobilize the $\mathrm{Cd}, \mathrm{Zn}$ and $\mathrm{Pb}$ in the sludge.

As for the immobilization mechanism of heavy metals, Lombi et al. (2003) and Hofstede (1994) suggested that the major immobilization mechanism is sorption and precipitation. Bruemmer et al. (1988) and Gray et al. (2006) suggested that specific chemisorption plays an important role for the immobilization of heavy metals. As for the 


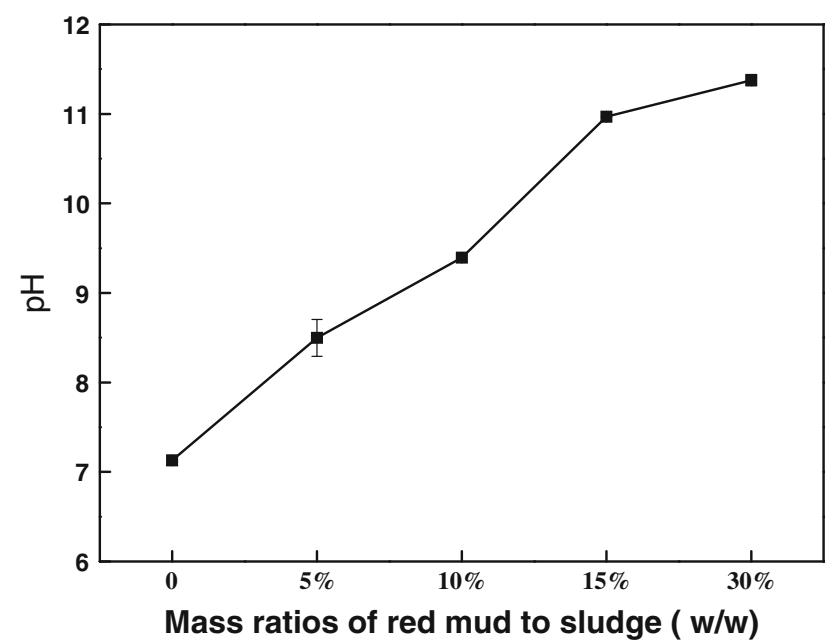

Fig. 1 The $\mathrm{pH}$ values of mixtures

immobilization of heavy metals in sewage sludge by red mud, it seems that the immobilization mechanism is a combination of precipitation and sorption. First, the immobilization is a result of an increase in mixture $\mathrm{pH}$ caused by the addition of this alkaline product. The alkalinity in the red mud precipitated heavy metals through the formation of $\mathrm{Cd}, \mathrm{Zn}$ and $\mathrm{Pb}$ hydroxides and carbonates. Second, red mud contains iron and aluminum oxides, which could adsorb heavy metals by sorption.

\section{Effect of amendment on plant available heavy metals}

Red mud amendment not only reduced the heavy metal leaching, but also reduced the content of plant available heavy metals. The changes in the content of plant available $\mathrm{Cd}, \mathrm{Zn}$ and $\mathrm{Pb}$ of red mud amended sewage sludge were shown in Fig. 3. It can be seen that, amendment by red mud significantly reduced the content of plant available heavy metals. For $\mathrm{Zn}$, the plant available percentage was decreased from 17.22 to $11.36 \%$ after the sludge was amended red mud. For $\mathrm{Cd}$, the plant available percentage was decreased from 18.13 to $6.98 \%$. For $\mathrm{Pb}$, the plant available percentage was decreased from 13.64 to $7.12 \%$.

\section{Effect of amendment on heavy metal speciation}

To identify the changes of heavy metals speciation resulting from the immobilization of the red mud amendment, unamended and amended sewage sludge samples were analyzed by sequential extraction experiments. This method provided useful evidence for explaining the heavy metals immobilization. At present, the sequential chemical extraction method by Tessier et al. (1979) and BCR (European Community Bureau of Reference) sequential extraction are the main methods for analysis the heavy
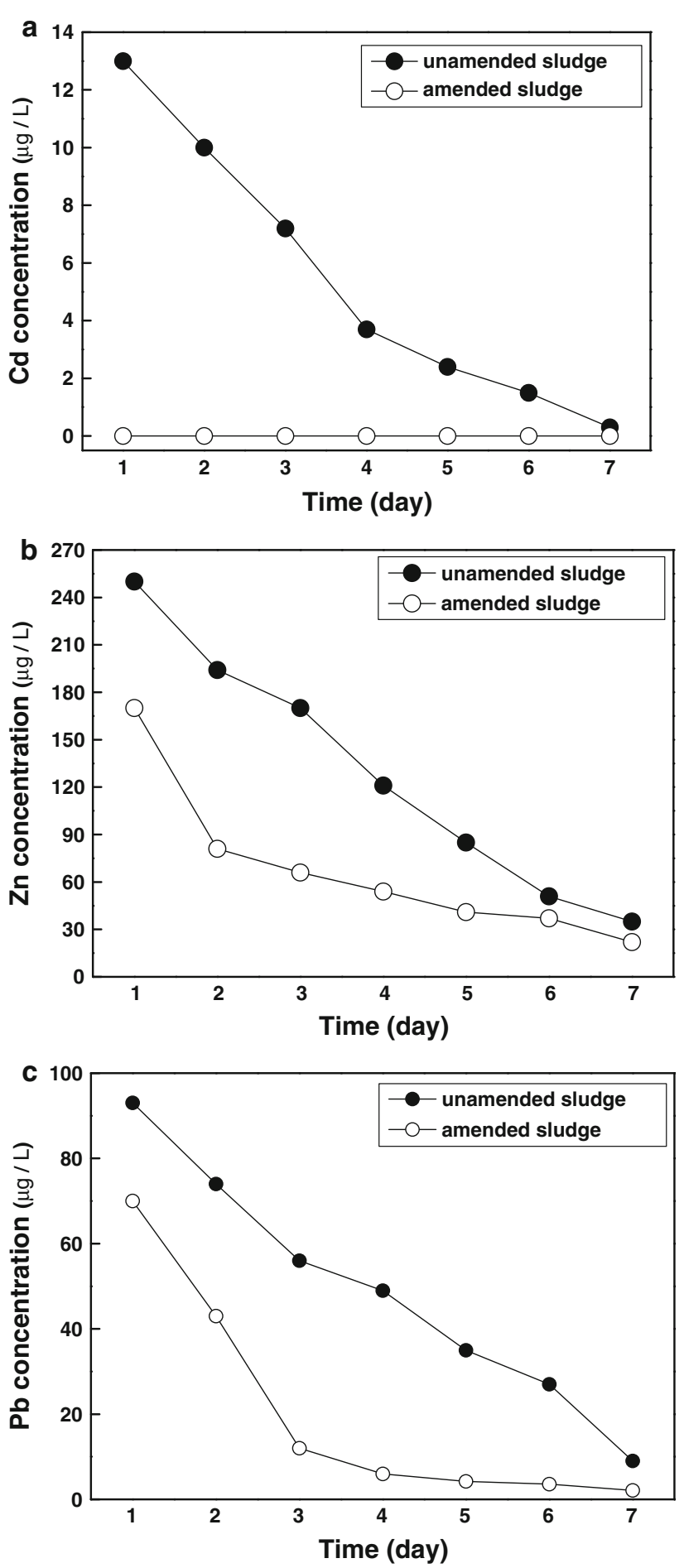

Fig. 2 Heavy metal concentrations in the leachate

metal speciation (Soylak et al. 2004; Saracoglu et al. 2009; Nemati et al. 2011; Alonso Castillo et al. 2011). In this paper, the sequential chemical extraction method by Tessier et al. (1979) was chosen. The heavy metal fractions in the sequential extraction experiments are shown in Fig. 4.

It can be seen from Fig. 4 that main Cd fraction in the sludge was bound to organic matter $(55.50 \%)$, followed by 


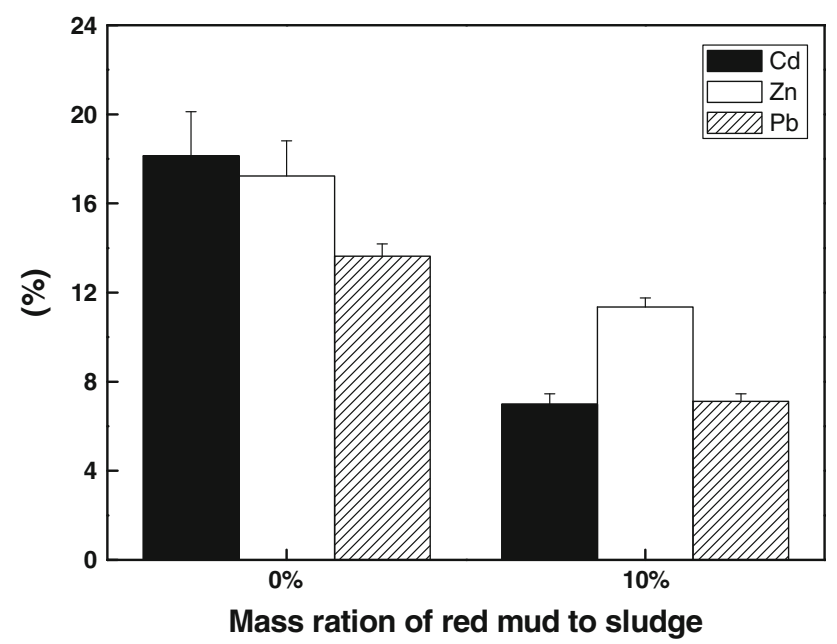

Fig. 3 Percentage of plant available heavy metals

exchangeable (13.46\%), bound to carbonates (12.69\%), residual $(9.30 \%)$ and bound to iron and manganese oxides $(9.04 \%)$. After red mud was mixed with sewage sludge, the $\mathrm{Cd}$ fraction pattern changed. Exchangeable fraction decreased from 13.46 to $5.32 \%$ and the carbonates and iron and manganese oxides fractions increased from 12.69 and $9.04 \%$ to 14.60 and $15.19 \%$, respectively. The organic matter and residual fractions only decreased slightly.

It can be observed that the order for different fractions of $\mathrm{Zn}$ in the sludge is: Bound to organic matter $(61.51 \%)>$ Residual $(23.37 \%)>$ Exchangeable $(10.10 \%)>$ Bound to iron and manganese oxides $(3.64 \%)>$ Bound to carbonates $(1.37 \%)$. The organic matter and residual fractions are high in the sewage sludge. The addition of red mud amendment did not cause marked changes of $\mathrm{Zn}$ speciation (Fig. 4). However, compared with the unamended sludge, the exchangeable fraction decreased from 10.10 to $0.14 \%$. Bound to carbonates fraction increased from 1.37 to $2.97 \%$ and the iron and manganese oxides fraction increased from 3.6 to $15.01 \%$. The organic matter and residual fractions decreased from 61.51 and $23.40 \%$ to 59.26 and $22.61 \%$.

$\mathrm{Pb}$ in the sludge was associated primarily with organic matter $(35.36 \%)$ and carbonates $(22.78 \%)$ fractions. Red mud was efficient in reducing the exchangeable fraction. The addition of red mud amendment shifted the distribution of $\mathrm{Pb}$ from the exchangeable fraction to the carbonates, iron and manganese oxides and residual fractions.

From the results obtained, it seems that the increase in $\mathrm{pH}$ of mixture (Fig. 1), due to the alkaline of red mud amendment, resulted in an increase of heavy metals associated with the carbonate fraction. Moreover, red mud which is rich in iron and aluminum oxides that have reactive surface sites able to bind metals caused a significant portion of exchangeable heavy metals to be associated with the iron and manganese oxides fraction. This result is
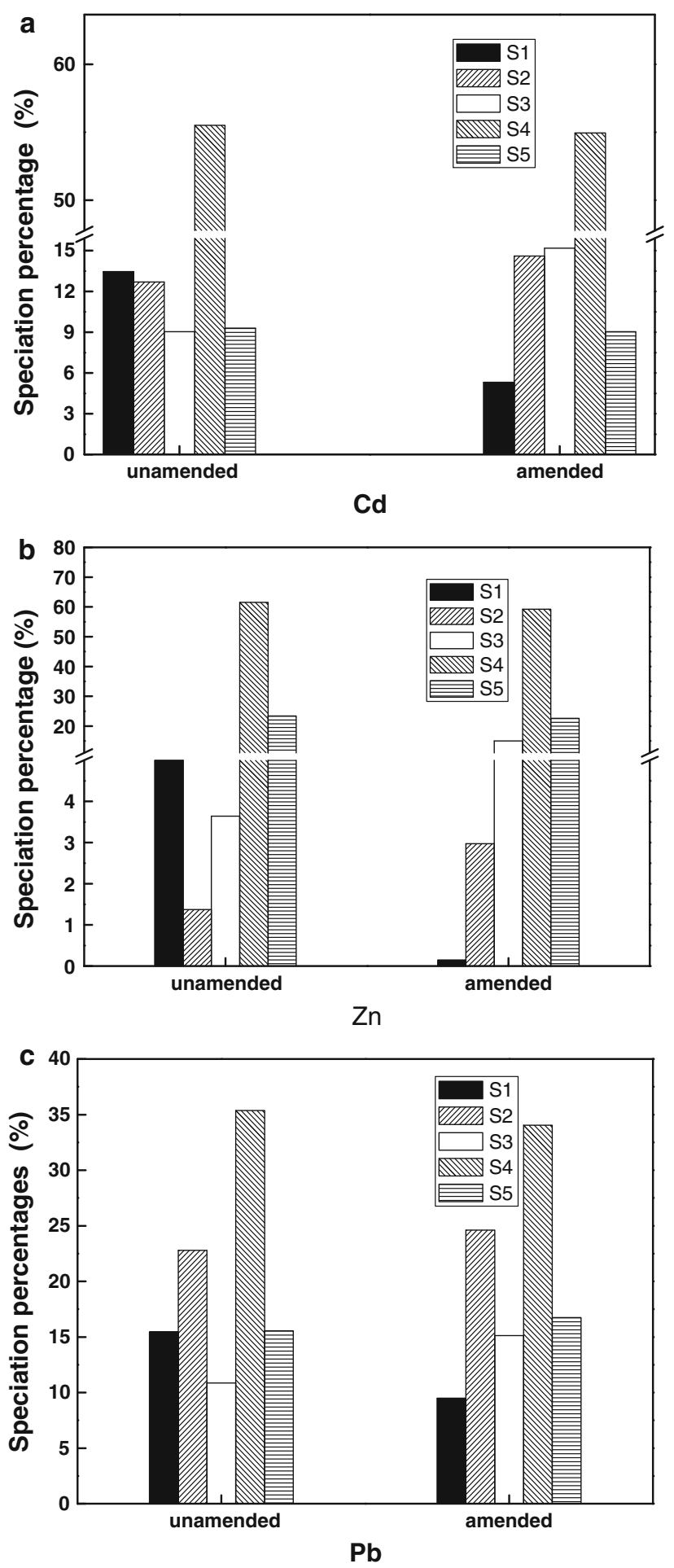

Fig. 4 Heavy metal speciation in unamended and amended sewage sludge

consist with Lombi et al. (2002a) who have used chemical extraction experiments to show that amending contaminated soils with red mud results in a distribution of heavy metals from exchange fraction to iron and manganese oxides fraction. 


\section{Conclusions}

1. Red mud amendment can effectively immobilize $\mathrm{Cd}$, $\mathrm{Zn}$ and $\mathrm{Pb}$ in sewage sludge. When sewage sludge mixed with $10 \%$ red mud, the immobilization efficiency of $\mathrm{Cd}, \mathrm{Zn}$ and $\mathrm{Pb}$ was 100,92 , and $82 \%$, respectively.

2. Plant available heavy metals $(\mathrm{Cd}, \mathrm{Zn}$ and $\mathrm{Pb})$ were reduced after sewage sludge was amended with $10 \%$ red mud. The plant available heavy metals $(\mathrm{Cd}, \mathrm{Zn}$ and $\mathrm{Pb})$ were reduced from $18.13,17.22$ and $13.64 \%$ to $6.98,11.36$ and $7.12 \%$, respectively.

3. Sequential chemical extraction experiments showed that after sewage sludge was amended with $10 \%$ red mud, exchangeable fraction was reduced and iron and manganese oxides fraction was increased.

Acknowledgments Financial support provided by National Water Pollution Control and Management Technology Major Projects (under Grant No. 2009ZX07104-005), National High Technology R\&D Program (863) from Ministry of Science Technology of China (under Grant No. 2009AA062906) the Public Industry Research for National Environmental Protection (under Grant No. 201009037) is gratefully acknowledged. The authors thank Research Institute of China Aluminum Industry Shandong Branch Company and Xiaohongmen sewage treatment plant, for providing the red mud and sewage sludge, respectively.

\section{References}

Alonso Castillo ML, Vereda Alonso E, Siles Cordero MT, Cano Pavon JM, Garcia de Torres A (2011) Fractionation of heavy metals in sediment by using microwave assisted sequential extraction procedure and determination by inductively coupled plasma mass spectrometry. Microchem J doi:10.1016/j.microc.2011.02.004

Alvarez EA, Mochon MC, Sanchez JCJ, Rordriguez MT (2002) Heavy metal extractable forms in sludge from wastewater treatment plants. Chemosphere 47:765-775

Angelidis M, Gibbs RJ (1991) Heavy metals in urban sewage sludges: chemical forms and possible availability. In: Proceedings of the treatment and use of sewage sludge and liquid agricultural wastes symposium. Elsevier, London, pp 400-404

Arthur DS (2004) Annual book of ASTM standards. ASTM Intl, USA

Basta NT, McGowenb SL (2004) Evaluation of chemical immobilization treatments for reducing heavy metal transport in a smelter-contaminated soil. Environ Pollut 127:73-82

Basta NT, Gradwohl R, Snethen KL, Schroder JL (2001) Chemical immobilization of lead, zinc, and cadmium in smelter-contaminated soils using biosolids and rock phosphate. J Environ Qual 30:1222-1230

Bertocchi AF, Ghiani M, Peretti R, Zucca A (2006) Red mud and fly ash for remediation of mine sites contaminated with $\mathrm{As}, \mathrm{Cd}, \mathrm{Cu}$, $\mathrm{Pb}$ and $\mathrm{Zn}$. J Hazard Mater 134:112-119

Brown S, Christensen B, Lombi E, McLaughlin M, McGrath S, Colpaert J, Vangronsveld J (2005) An inter-laboratory study to test the ability of amendments to reduce the availability of $\mathrm{Cd}$, $\mathrm{Pb}$, and $\mathrm{Zn}$ in situ. Environ Pollut 138:34-45

Bruemmer GW, Gerth J, Tiller KG (1988) Reaction kinetics of the adsorption and desorption of nickel, zinc and cadmium by goethite. I. Adsorption and diffusion of metals. Eur J Soc Sci 39:37-52

Cai QY, Mo CH, Wu QT, Zeng QY, Athanasios K (2007) Concentration and speciation of heavy metals in six different sewage sludge-composts. J Hazard Mater 147:1063-1072

Cao RX, Ma LQ, Chen M, Singh SP, Harris WG (2003) Phosphateinduced metal immobilization in a contaminated site. Environ Pollut 122:19-28

Cao XD, Wahbi A, Ma L, Li B, Yang YL (2009) Immobilization of $\mathrm{Zn}, \mathrm{Cu}$, and $\mathrm{Pb}$ in contaminated soils using phosphate rock and phosphoric acid. J Hazard Mater 164:555-564

Chen M, Ma LQ, Singh SP, Cao RX, Melamed R (2003a) Field demonstration of in situ immobilization of soil $\mathrm{Pb}$ using $\mathrm{P}$ amendments. Adv Env Res 8:93-102

Chen TB, Huang QF, Gao D (2003b) Heavy metal concentrations and their decreasing trends in sewage sludges of China. Acta Scientiae Circumstantiae 23:561-569

Ciccu R, Ghiani M, Serci A, Fadda S, Peretti R, Zucca A (2003) Heavy metal immobilization in the mining-contaminated soils using various industrial wastes. Miner Eng 16:187-192

Dimitris D, Meng XG (2003) Utilization of fly ash for stabilization/ solidification of heavy metal contaminated soils. Eng Geol 70:377-394

Fuentes A, Llorens M, Saez J, Aguilar I, Perez-Marin AB, Ortuno JF, Meseguer VF (2006) Ecotoxicity, phytotoxicity and extractability of heavy metals from different stabilised sewage sludges. Environ Pollut 143:355-360

Gadepalle VP, Ouki SK, Herwijnen RV, Hutchings T (2007) Immobilization of heavy metals in soil using natural and waste materials for vegetation establishment on contaminated sites. Soil Sediment Contam 16:233-251

Garau G, Castaldi P, Santona L, Deiana P, Melis P (2007) Influence of red mud, zeolite and lime on heavy metal immobilization, culturable heterotrophic microbical populations and enzyme activities in a contaminated soil. Geoderma 142:47-57

Gray CW, Dunham SJ, Dennis PG, Zhao FJ, McGrath SP (2006) Field evaluation of in situ remediation of a heavy metal contaminated soil using lime and red-mud. Environ Pollut 142:530-539

Gu XY, Wong JWC (2004) Identification of inhibitory substances affecting bioleaching of heavy metals from anaerobically digested sewage sludge. Environ Sci Technol 38:2934-2939

Hettiarachchi GM, Pierzynski GM, Ransom MD (2000) In situ stabilization of soil lead using phosphorus and manganese oxide. Environ Sci Technol 34:4614-4619

Hofstede H (1994) Use of bauxite refining residue to reduce the mobility of heavy metals in municipal waste compost, $\mathrm{PhD}$ thesis, School of Biological and Environmental Science Murdoch University, Western Australia

Kumpiene J, Lagerkvist A, Maurice C (2007) Stabilization of Pb and $\mathrm{Cu}$ contaminated soil using coal fly ash and peat. Environ Pollut 145:365-373

Lee DJ, Spinosa L, He PJ, Chen TB (2006) Sludge production and management processes case study in China. Water Sci Technol 54:189-196

Liang Z, Wang J, Peng XJ, Li YR, Zhao Y, Luan ZK (2010) Red mud and modified red mud for remediation of soil contaminated with arsenic. Fresen Environ Bull 19:489-494

Lindsay WL, Norvell WA (1978) Development of a DTPA soil test for zinc, iron, manganese and copper. Soil Sci Soc Am J 42:421-428

Liu YS, Ma LL, Li YQ, Zheng LT (2007) Evolution of heavy metal speciation during the aerobic composting process of sewage sludge. Chemosphere 67:1025-1032

Lombi E, Zhao FJ, Wieshammer G, Zhang GY, McGrath SP (2002a) In situ fixation of metals in soils using bauxite residue: biological effects. Environ Pollut 118:445-452 
Lombi E, Zhao FJ, Zhang GY, Sun B, Fitz W, Zhang H, McGrath SP (2002b) In situ fixation of metals in soils using bauxite residue: chemical assessment. Environ Pollut 118:435-443

Lombi E, Hamon RE, McGrath SP, Mclaughlin MJ (2003) Lability of $\mathrm{Cd}, \mathrm{Cu}$, and $\mathrm{Zn}$ in polluted soils treated with lime, beringite, and red mud and identification of a non-labile colloidal fraction of metals using isotopic techniques. Environ Sci Technol 37:979-984

Miles LJ, Parker GR (1979) DTPA soil extractable and plant heavy metal concentrations with soil amended Cd treatments. Plant Soil 51:59-68

Mingot JL, Obrador A, Alvarez JM, Rico MI (1995) Acid extraction and sequential fractionation of heavy metals in water treatment sludges. Environ Technol 16:869-876

Muller I, Pluquet E (1998) Immobilization of heavy metals in sediment dredged from a seaport by iron bearing materials. Water Sci Technol 37:379-386

Nemati K, Bakar NKA, Abas MRB, Sobhanzadeh E, Low KH (2011) Comparison of unmodified and modified BCR sequential extraction schemes for the fractionation of heavy metals in shrimp aquaculture sludge from Selangor, Malaysia. Environ Monit Assess. doi:10.1007/s10661-010-1584-3

Qiao XL, Luo YM, Christie P, Wong MH (2003) Chemical speciation and extractability of $\mathrm{Zn}, \mathrm{Cu}$ and $\mathrm{Cd}$ in two contrasting biosolidsamended clay soils. Chemosphere 50:823-829
Querol X, Alastuey A, Moreno N, Alvarez-Ayuso E, Garcia-Sanchez A, Cama J, Ayora C, Simon M (2006) Immobilization of heavy metals in polluted soils by the addition of zeolitic material synthesized from coal fly ash. Chemosphere 62:171-180

Reyhanitabar A, Gilkes RJ (2009) Kinetics of DTPA extraction of zinc from calcareous soils. Geoderma 154:289-293

Saracoglu S, Soylak M, Elci L (2009) Extractable trace metals contents of dusts of air filters from vehicles by sequential extraction procedure. J Aoac Int 92:1196-1202

Scheckel KG, Ryan JA (2004) Spectroscopic speciation and quantification of Lead in phosphate-amended soils. J Environ Qual 33:1288-1295

Schnitzer M, Skinner SIM (1966) Organo-metallic interactions in soils: 5 Stability constants of $\mathrm{Cu}^{++}, \mathrm{Fe}^{++}$and $\mathrm{Zn}^{++}$fulvic acid complexes. Soil Sci 102:361-365

Soylak M, Uzek U, Narin I, Tuzen M, Turkoglu O, Elci L (2004) Application of the sequential extraction procedure for dust samples from Kayseri-Turkey. Fresen Environ Bull 13:454-457

Tessier A, Campbell PGC, Bisson M (1979) Sequential extraction procedure for the speciation of particulate trace metals. Anal Chem 51:844-851

Wang W, Luo YX, Qiao W (2010) Possible solutions for sludge dewatering in China. Front Environ Sci Eng China 4:102-107

Wong JWC, Li K, Fang M, Su DC (2001) Toxicity evaluation of sewage sludges in Hong Kong. Environ Int 27:373-380 